\title{
Relationship of Chewing Tobacco Intake and Food Consumption with High Fondues Uteri on Pregnant Mother in Simalungun District
}

\author{
Evawany Yunita Aritonang ${ }^{\#}$, Albiner Siagian ${ }^{\#}$ \\ \# Community Nutrition Department, University of Sumatera Utara, Medan, 20155, Indonesia \\ E-mail: evawany@gmail.com; albiner_sgn@yahoo.com
}

\begin{abstract}
Chewing tobacco is a tobacco that people consume by chewing. The main content of substances in tobacco is nicotine that is harmful to health because it poisoned pregnancy. The results of Indonesia's basic health research in 2013 revealed the prevalence of smoking and chewing tobacco consumption was $36.3 \%$. This survey showed that iron deficiency anaemia in pregnant mother also high was 29\%. District Bangun Purba Simalungun Regency is an area where chewing tobacco consumption done in many people, not only elderly but also young people including pregnant mother. The aim of this research is to analyze the relationship of chewing tobacco intake and food consumption with high fondues uteri in pregnant mother with cross sectional study design. The sample was 94 pregnant mothers second trimester and third trimester. The results showed that $31.9 \%$ pregnant mother have below adequacy protein consumption and $35.1 \%$ pregnant mothers have below adequacy iron consumption. The research also showed that $36.2 \%$ mothers have abnormal the high fondues uteri and only $\mathbf{6 3 . 8 \%}$ mothers in normal category of high fondues uteri. Chewing tobacco intake is still performed on some pregnant mother whose frequency varies from frequency to occasional frequency to day. Statistical analysis showed positive correlation between chewing tobacco intake during pregnancy and high fondues uteri. The other hands, chewing tobacco intake before pregnancy is not significantly related with high fondues uteri. Although there is no correlation between chewing tobacco intake before pregnancy with high fondues uteri does not mean that chewing tobacco may be consumed by pregnant mother. Socialization of chewing tobacco habits in pregnant mother should be done by health workers at Bangun Purba Health Centre and Simalungun District Health Office
\end{abstract}

Keywords - chewing tobacco; food consumption; fondues uteri; pregnant mother.

\section{INTRODUCTION}

Indonesia's tobacco production in 2012 was 226.704 tons, making Indonesia as the 5th largest producer of tobacco. Although tobacco production in Indonesia is large, but the demand for tobacco is so high that Indonesia must be imports tobacco. Tobacco imports increased from 65.6 thousand tons in 2010 to 106.5 thousand tons in 2011. In addition, the number of tobacco farmers also increased from 680,000 people in 2010 to 786,000 in 2012 [1].

In Indonesia, $67.4 \%$ of men and $4.5 \%$ of women comprising $36.1 \%$ of the population (61.4 million) currently use tobacco in smoked or smokeless form. Tobacco use is more prevalent in rural areas $(39.1 \%)$ as compared to urban areas $(33.0 \%)$. In Indonesia, smoking is the main form of tobacco use and $34.8 \%$ (59.9 million) of the adult population currently smoke tobacco. The prevalence of smoking is $67.0 \%$ (57.6 million) among men and $2.7 \%$ ( 2.3 million) among women. Among the adult population, $56.7 \%$ of adult men (57.6 million), $1.8 \%$ of adult women (1.6 million) and $29.2 \%$ overall (50.3 million) are daily smokers. Currently, smoking is more prevalent in rural areas $(37.7 \%)$ as compared to urban areas $(31.9 \%)$ [2].

The prevalence of tobacco consumption tends to increase in both men and women. The increase in prevalence was greater in women than $1.7 \%$ in 1995 to $6.7 \%$ in 2013, while in men from $53.4 \%$ in 1995 to $66 \%$ in 2013 . The highest proportion of provinces in Indonesia consuming tobacco is East Nusa Tenggara (55.6\%) [1].

During 2000-2015, in the United States total smokeless tobacco consumption increased $23.1 \%$ ( $\mathrm{p}<0.05)$, or $4.2 \%$ per capita. However, chewing tobacco and smoke tobacco consumption patterns diverged; total chewing tobacco consumption decreased $55.8 \%$ from 45.6 to 20.2 billion pounds (from 20.7 to 9.2 billion kilograms) $(\mathrm{p}<0.05)$, whereas total chewing tobacco consumption increased $77.5 \%$ from 66.2 to 117.4 billion pounds (from 30.0 to 53.3 billion kilograms $)(\mathrm{p}<0.05)[3]$.

In Indonesia, the proportion of people aged $\geq 15$ years who smoked and chewed tobacco tended to increase. Indonesia basic health survey in year 2007 stated that there were $34.2 \%$ of the population of $\geq 15$ years who smoked and chewed tobacco. The same survey in 2010 stated there are 
$34.7 \%$ of the population of $\geq 15$ years who smoke and chew tobacco and survey in 2013 stated there are as many as $36.3 \%$ of the population $\geq 15$ years who smoked and chewed tobacco.

One study stated that smoked or chewed tobacco depend on occupational. The men or women who were work more intake cigarettes and tobacco than those who do not work. According to age, tobacco and tobacco consumption from year to year has a pattern that is almost as good in men and women. The lowest consumption was in the 15-24 years age group then increased to peak between the ages of 35-54 years and again decreased at the age of 55 years and over [1].

Related to chewing tobacco consumption, in the women group the prevalence increase occurred up to two times for chewing tobacco consumption. The high prevalence is due in part to the culture of chewing tobacco in some provinces. In the male group smoked more, while in the group of women more chewing tobacco. It was like usual habit [4].

Tobacco chemical content that has been identified amounted to 2.500 components. There are 1.100 components are reduced to smoke components directly and 1.400 others decompose or split, react with other components and form new components. In the smoke, there were 4800 kinds of chemical components that have been identified. Some of chemical components in cigarettes that is hazardous to the health, such as CO gas, tar, nicotine, and NO from tobacco. Harmful materials are maybe formed during planting, processing, and serving in trade, namely residues of $\mathrm{BaP}$ (benzo-a-pyrene), and NTRM (non-tobacco related materials), fertilizers and pesticides, TSNA (tobacco specific nitrosamine) [5].

Trend of maternal mortality rate in Indonesia has been increasing in the last 5 years which is one of the countries with the highest mortality rate in Southeast Asia. The biggest cause of maternal death is bleeding and eclampsia. Bleeding in pregnant mother is due to iron deficiency anaemia so that haemoglobin levels in pregnant mother are generally still low should be corrected to prevent the occurrence of bleeding that affects maternal mortality [6]. In other hand, blood pressure of pregnant mother as an indicator eclampsia that must be managed because high risk to the occurrence of eclampsia.

Consumption of harmful substances that can interfere with pregnancy consisted of caffeine, alcohol, and cigarettes should be avoided. Tobacco is the main ingredient in cigarettes processed from Nicotiana plant leaves. World Health Organization (WHO) states that tobacco-related deaths around the world have been very worrying about 100 million during the 20th and 1st centuries during the 21st century if there is no prevention of tobacco consumption [7].

The expected quality of pregnancy includes the health status of pregnant mother and the health status of the foetus. This can be known from several quality pregnancy indicators such as pregnancy weight gain, high fondues uteri, blood haemoglobin level, blood pressure, and baby's birth weight [8]. Tobacco chewing habit is mostly done in some areas in Indonesia such as Java and North Sumatera which is mostly done by women than men. In North Sumatera is generally mostly done by Batak Karo tribe. Chewing tobacco is tobacco that is not smoked, formed from long strands of tobacco that just crushed roughly and placed on the cheek between the gums and teeth to chew. The tradition of chewing tobacco consumption has been long and continuous because traditional markets provide these tobacco materials at any time so it is not difficult to get the need of tobacco chewing. The process of chewing in the syringe also uses other mixtures such as rubiaceae, areca nut, piper leaf, and piper lime.

In general there are still many people who do not know the effects of chewing tobacco. The results revealed that nicotine in tobacco is a carcinogen that causes an increased risk of bladder cancer 400 percent higher in chewing tobacco consumption than non-chewing tobacco consumers [9]. The effects of nicotine on tobacco smoked through cigarettes, chewed or inhaled lead to increased heart rate and blood pressure, anorexia, and constriction of blood vessels. Another effect stated that the risk factors due to chewing tobacco consumption will remain for several years even after the user actually stops chewing tobacco consumption [2]. Simalungun District is an area where people consume chewing tobacco. Consumption of chewing tobacco is not only done by old age but also mostly done by a young age including pregnant mother. This can be seen from the many red lips of society in this region. Based on the pre survey is also known that the habit of chewing tobacco consumption in this region has been long and hereditary. Based on the impact of chewing tobacco on health, the researcher want to analysed the relationship of chewing tobacco consumption and food consumption with high fondues uteri in pregnant mother in Simalungun District.

\section{MATERIAL AND METHOD}

\section{A. Design, Time and Location Research}

This research is an analytical descriptive research with cross sectional study design. The study will be conducted during 6 months, starting from May to October 2017, in Simalungun District, North Sumatera Province.

\section{B. Population and Sample}

The population is all second and third trimester of pregnant mother in Simalungun Regency, that were 129 people. The sample is a portion of the population whose amount is determined based on the following sample calculation formula:

$$
\begin{aligned}
\mathrm{n}=\quad & \frac{\mathrm{N} . \mathrm{Z}^{2} 1-\alpha / 2 . \mathrm{p} \cdot \mathrm{q}}{\mathrm{d}^{2}(\mathrm{~N}-1)+\mathrm{Z}^{2} 1-\alpha / 2 . p . q} \\
\mathrm{n} \quad & =\text { number of samples } \\
\mathrm{N} \quad & \text { Population } \\
\mathrm{d} \quad & =5 \% \\
\mathrm{p} & =15 \% \\
\mathrm{Z}(1-\alpha / 2) & =1.96 \\
\mathrm{n} \quad & \quad \frac{129(1.96)^{2} \cdot 0,15 \cdot 0.85}{0.05)^{2}(128)+1.96^{2} \cdot 0.15 \cdot 0.85} \\
& =\frac{495.57(0.13)}{0.32+0.49} \\
& =\frac{64.42}{0.81} \\
& =79.53 \\
& =80 \text { people }
\end{aligned}
$$

Based on the formula of minimum sample calculation, the minimum sample size is 80 , so that $\pm 10 \%$ is added and 
the sample number is 94 pregnant mothers. Sampling method is done by random sampling.

\section{Data Analysis}

The data analyses in univariate and bivariate analysis. Data food consumption analysed with Nutrisurvey program. High fondues uteri categorized as normal and not normal based on the requirement. Statistical analysis with chi square used to know the relationship of food consumption and chewing tobacco intake with high fondues uteri done.

\section{RESULTS AND DISCUSSION}

\section{A. Characteristics of Pregnant Mother}

TABLE I

The Characteristics of Pregnant Mother

\begin{tabular}{|c|c|c|c|}
\hline No & $\begin{array}{c}\text { Characteristics of Pregnant } \\
\text { mother }\end{array}$ & $\mathbf{n}$ & $\%$ \\
\hline 1 & $\begin{array}{l}\text { Age (year) } \\
\bullet \quad<20 \\
\cdot \quad 20-35 \\
\bullet \quad>35\end{array}$ & $\begin{array}{r}5 \\
89 \\
0\end{array}$ & $\begin{array}{r}5.3 \\
94.7 \\
0.0\end{array}$ \\
\hline 2 & $\begin{array}{ll}\text { Parity } \\
-\quad 0 \\
-\quad 1-2 \\
-\quad>2 \\
\end{array}$ & $\begin{array}{l}13 \\
47 \\
34\end{array}$ & $\begin{array}{l}13.8 \\
50.0 \\
36.2\end{array}$ \\
\hline 3 & \begin{tabular}{ll}
\multicolumn{2}{l}{ Age of Pregnant } \\
- & Second Trimester \\
- & Third Trimester
\end{tabular} & $\begin{array}{l}67 \\
27\end{array}$ & $\begin{array}{l}71.3 \\
28.7\end{array}$ \\
\hline 4 & $\begin{array}{ll} & \text { Education Mother } \\
\text { - } & \text { Primary and Junior High } \\
\text { - School } \\
\text { - Senior High School } \\
\text { - University }\end{array}$ & $\begin{array}{r}40 \\
47 \\
7\end{array}$ & $\begin{array}{r}42.6 \\
50.0 \\
7.4\end{array}$ \\
\hline 5 & $\begin{array}{l}\text { Mother's Occupational } \\
\text { - } \quad \text { Farmers } \\
\text { - } \quad \text { Nurses, employees } \\
\text { - } \quad \text { Entrepreneur }\end{array}$ & $\begin{array}{r}80 \\
2 \\
12\end{array}$ & $\begin{array}{r}85.1 \\
2.1 \\
12.8\end{array}$ \\
\hline 6 & $\begin{array}{l}\text { Family Income } \\
\text { - } \quad \text { < Regional Minimum Wage } \\
-\quad \geq \text { Regional Minimum Wage }\end{array}$ & $\begin{array}{l}67 \\
27\end{array}$ & $\begin{array}{l}71.3 \\
28.7\end{array}$ \\
\hline
\end{tabular}

\section{B. Fondues Uterine of Pregnant Mother}

TABLE II

FONDUES UTERI NE OF PREGNANT MOTHER

\begin{tabular}{|c|ll|l|l|}
\hline No & \multicolumn{1}{|c|}{$\begin{array}{c}\text { High Fondues Uterine of } \\
\text { Pregnant mother }\end{array}$} & $\mathbf{n}$ & \% \\
\hline 1 & $\bullet$ & Normal & 60 & 63.8 \\
& $\bullet \quad$ Abnormal & 34 & 36.2 \\
\hline
\end{tabular}

\section{Food Consumption of Pregnant Mother}

TABLE III

FOOD CONSUMPTION OF PREGNANT MOTHER

\begin{tabular}{|c|c|c|c|}
\hline No & Food Consumption & n & \% \\
\hline 1 & Energy Consumption & & \\
& $\bullet \quad$ Excessive & 18 & 19.1 \\
& $\bullet \quad$ Good & 44 & 46.8 \\
& $\bullet \quad$ Deficit & 32 & 34.0 \\
\hline 2 & Protein Consumption & 18 & 19.1 \\
\hline
\end{tabular}

\begin{tabular}{|c|c|c|c|}
\hline & $\bullet$ Good & 46 & 48.9 \\
& $\bullet$ Deficit & 30 & 31.9 \\
\hline 3 & Iron Consumption & & \\
& $\bullet$ Excessive & 23 & 24.5 \\
& $\bullet$ Good & 38 & 40.4 \\
& $\bullet$ Deficit & 33 & 35.1 \\
\hline
\end{tabular}

D. Habits of Chewing Tobacco Consumption in Pregnant mother

TABLE IV

Habits Of Chewing Tobacco Consumption In PRegnant Mother

\begin{tabular}{|c|c|c|c|}
\hline No & Chewing Tobacco Consumption & $\mathbf{N}$ & $\%$ \\
\hline 1 & $\begin{array}{l}\text { Habits of Chewing Tobacco } \\
\text { Consumption during Pregnancy } \\
\text { - Yes } \\
\text { - No }\end{array}$ & $\begin{array}{l}58 \\
36\end{array}$ & $\begin{array}{l}61.7 \\
38.3\end{array}$ \\
\hline 2 & $\begin{array}{l}\text { Long Consumption of Chewing } \\
\text { Tobacco } \\
\text { - } \quad<6 \text { month } \\
\text { - } 6-12 \text { month } \\
\text { - } \quad>12 \text { month }\end{array}$ & $\begin{array}{l}15 \\
11 \\
28\end{array}$ & $\begin{array}{l}16.0 \\
11.7 \\
29.8\end{array}$ \\
\hline 3 & 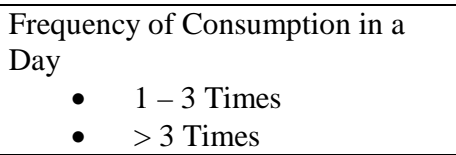 & $\begin{array}{l}26 \\
28\end{array}$ & $\begin{array}{l}27.7 \\
29.8\end{array}$ \\
\hline 4 & $\begin{array}{cc}\text { Type of Tobacco } \\
\text { • } & \text { Yellow Tobacco } \\
\bullet & \text { Green Tobacco } \\
\text { - } & \text { Black Tobacco } \\
\end{array}$ & $\begin{array}{r}37 \\
14 \\
3\end{array}$ & $\begin{array}{r}39.4 \\
14.9 \\
3.2 \\
\end{array}$ \\
\hline
\end{tabular}

E. Relationship of Chewing Tobacco Consumption and High Fondues Uterine

TABLE V

RELATIONSHIP OF CHEWING TOBACCO CONSUMPTION AND High Fondues UTERI

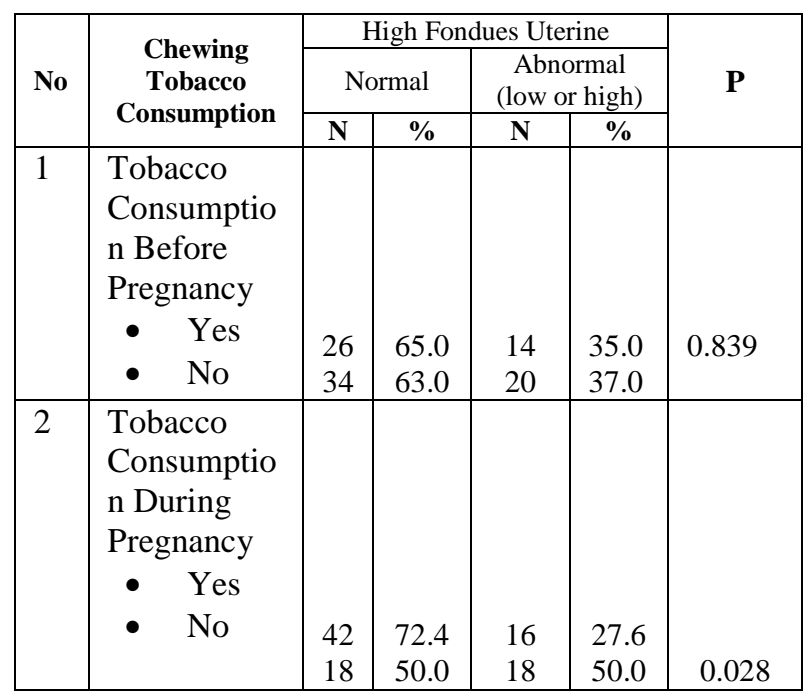

F. Relationship of Food Consumption and High Fondues Uteri 
TABLE VI

FOOD CONSUMPTION RELATIONSHIP WITH HIGH FONDUES UTERI

\begin{tabular}{|c|c|c|c|c|c|c|}
\hline \multirow[t]{3}{*}{ No } & \multirow[t]{3}{*}{ Consumption of Food } & \multicolumn{4}{|c|}{ High Fondues Uteri Pregnant mother } & \multirow[t]{3}{*}{$\mathrm{P}$} \\
\hline & & \multicolumn{2}{|c|}{ Normal } & \multicolumn{2}{|c|}{ Abnormal (Low or High) } & \\
\hline & & $\mathrm{N}$ & $\%$ & $\mathrm{~N}$ & $\%$ & \\
\hline 1 & $\begin{array}{l}\text { Energy Consumption } \\
\text { - } \quad \text { Good } \\
\text { - } \quad \text { Not Good }\end{array}$ & $\begin{array}{l}29 \\
31\end{array}$ & $\begin{array}{l}78.4 \\
54.4\end{array}$ & $\begin{array}{c}8 \\
26\end{array}$ & $\begin{array}{l}21.6 \\
45.6\end{array}$ & 0.018 \\
\hline 2 & $\begin{array}{l}\text { Protein Consumption } \\
\text { - } \quad \text { Good } \\
\text { - } \quad \text { Not Good }\end{array}$ & $\begin{array}{l}28 \\
32\end{array}$ & $\begin{array}{l}70.0 \\
59.3\end{array}$ & $\begin{array}{l}12 \\
22\end{array}$ & $\begin{array}{l}30.0 \\
40.7\end{array}$ & 0.284 \\
\hline 3 & $\begin{array}{ll}\text { Iron } & \text { Consumption } \\
\text { - } & \text { Good } \\
\text { - } & \text { Not Good } \\
\end{array}$ & $\begin{array}{l}33 \\
27\end{array}$ & $\begin{array}{l}78.6 \\
51.9\end{array}$ & $\begin{array}{c}9 \\
25\end{array}$ & $\begin{array}{l}21.4 \\
48.1\end{array}$ & 0.008 \\
\hline
\end{tabular}

\section{G. Relationship of Habitual Consumption of Chewing Tobacco and High Fondues Uteri}

The results showed that mothers who consumed chewing tobacco were 40 mothers $(42.6 \%)$ and 54 mothers $(57.4 \%)$ not consumed chewing tobacco before pregnancy that have

abnormalities high fondues uteri. Statistical analysis showed that there is no significant correlation between chewing tobacco consumption before pregnancy with high fondues uteri. While mothers who consumed chewing tobacco during pregnancy were $61.7 \%$ and $38.3 \%$ mothers not consumed chewing tobacco that have abnormalities high fondues uteri. Statistical analysis showed that there is significant correlation between chewing tobacco consumption during pregnancy with high fondues uteri. This is due to the presence of nicotine in chewing tobacco resulted in disruption of nutrient intake required in foetus development so as to affect the abnormalities of high size fondues uteri because one indicator of foetus development is high fondues uteri. Based on this, chewing tobacco during pregnancy is a risky behaviour that has to avoid. Many people have trouble eliminating this habit. Pregnant women who consume tobacco give a worst influence on the condition of the fetus it contains. Carbon monoxide from tobacco will carry into the bloodstream to the fetus. This results in the distribution of oxygen and nutrients for the baby to be inhibited, resulting in reduced placental weight. Another adverse effect of tobacco is causing impairment of the placenta. The placenta extends the region within the uterus to meet the nutrient needs and foetus oxygen. This results in a decrease in the placental layer and the likelihood of placenta being lower or placenta previa (the placenta is present in the cervix) [10].

Chewing tobacco directly affects foetus growth and development, especially in the first trimester until the gestational age. Chemicals contains of tobacco such as nicotine, cyanide, lead, tar, carbon monoxide, is a compound that causing cancer. When these chemicals enter the bloodstream of pregnant women and enter the circulation of oxygen, it can inhibit nutrient intake in pregnant women and their fetus. The BMA Tobacco Control Resource Center study illustrates that mothers who consume tobacco during pregnancy are at risk of delivering low birth weight babies [7]. The research states that has siginificantly correlated between expenditure income and of number tobacco. Nicotine in tobacco is one of the known additives. Nicotine in central nervous system (CNS) inhibitor that disrupts the nerve balance. Physical and psychological dependence on nicotine develops very quickly.

Another research showed that smoking tobacco gives a nicotine effect on the CNS in ten seconds. If tobacco is chewed, effects on the CNS are experienced within 3-5 minutes [11]. The effects of tobacco nicotine used by sucking, chewing or inhaling tobacco with a straw, causing decreased appetite, partially eliminating feelings of taste and smell and making the lungs become painful, increased heart rate and blood pressure, and constriction of blood vessels.

\section{H. Food Consumption Relationship With Higher Uterine Pregnant's Fondues}

The results showed that the majority of food consumption with iron intake that affects maternal blood pressure as many as 25 people $(48.1 \%)$ high fondues uteri low or not normal. Result of analysis with Chi-square test show that probability is 0.008 means Ho rejected stated that there is a significant relationship between protein intake with high fondues uteri. Protein is a basic nutrient for foetus growth. Establishment of amnion cultivation, stash for daily activity needs, enlargement of the uterus, breast glands, and placentas. Food sources should be from animal food such as eggs, fish, lean meat and milk.

The need for healthy and high-protein foods is needed for the foetus during the pregnancy process. When pregnant mother lack protein or other nutrient intake then the body's resistance to fight germs will weaken and easy to get sick or infectious diseases, this situation is not good for foetus growth [12]. Iron intake is also needed for pregnant mother to prevent iron deficiency anemia during pregnancy and to keep the growth of foetus growing. In addition to foetal growth impact, anemias in pregnant mother also result in placenta disturbances such as hypertrophy, calcification, and infarction. This can lead to foetal growth disorders [8].

When a high uterine fondue is low in pregnant mother will affect the growth of the foetus. Pregnant mother with chronic energy deficiency have more risk to have high uterine fondues category low. High uterine fondues of less than $23.5 \mathrm{~cm}$ has a risk of stunted growth and development in the foetus so that the baby is born with LBW (low birth weight) [13].

Based on the results of research it is known that the weight of the foetus based on the height of the uterine fondues showed the average estimated weight of newborn 
$3.35 \mathrm{~kg}$ as many as 95 people $(95 \%)$ while the lowest estimated weight of babies is $2.32 \mathrm{~kg}$ as much as $1(1 \%)$ with a funding height of $26 \mathrm{~cm}$ and a heaviest of $4.03 \mathrm{~kg}$ as many as 4 people (4\%) with a $37 \mathrm{~cm}$ high uterine fondues.

Energy, protein and calcium intakes in the third trimester were significantly correlated with birth weight of neonates. The results showed that, the intake of energy was 1802 Kcal/day. The intake of protein, calcium, iron, zinc and magnesium were $70.7 \mathrm{~g}, 544.0 \mathrm{mg}, 16.1 \mathrm{mg}, 10.6 \mathrm{mg}$ and $266.0 \mathrm{mg}$ respectively. Percentage adequacy of nutrient intakes with reference to RDA recommendation showed $95 \%$ and $80 \%$ of subjects had sufficient RDA intakes, while energy, calcium, iron and zinc intake considered as insufficient. The mean birth weight of neonates was $3.0 \mathrm{~kg}$ and $13 \%$ of neonates showed low birth weight [14]

Nutritional status of pregnant women is known to influence quality and health of neonates. Birth weight is the most sensitive and reliable indicator of health for an infant and associated with the health and survival of them. Low birth weight (LBW) is an indicator of poor health of neonates. Considerable percentage of neonates $(87 \%)$ was classified as NBW and 13\% showed LBW. Similar percentage of results in Zahedan hospitals was reported that $12 \%$ of neonates had LBW [15].

There are many reason for variations in level of LBW may be different geographic regions and bioavailability of food is affected due to climate variations. Male neonates showed significantly higher height, weight, head and chest circumferences than females.

The relationship between maternal nutritional status and birth weight was examined to find out association between birth weight and nutritional status of pregnant women. NBW and LBW were considered as the parameters of birth weight. Pregnant mother who gave birth to LBW have low haemoglobin level than women who gave birth to neonates with normal birth weight babies. It was also observed that these women who gave birth to normal neonates had significantly higher consumption of energy and protein, calcium and iron than who gave birth to neonates with LBW.

\section{Fundus Uterine Pregnant Woman}

The uterus of a woman who is not pregnant weighs have 50 to 70 grams and is 7 to $9 \mathrm{~cm}$ long. While for pregnant mother in the end of pregnancy, the weighs of uterus nearly $1 \mathrm{~kg}$ and has a volume is 5 litres. During pregnancy, the uterus grows with the baby. Starting from the fourth month of pregnancy, the uterus rises from the pelvis, which results in visible changes in the mother's body. The fundus of the uterus in fourth month pregnancy is halfway between the pelvis and the navel and in week 24 it is up to the navel. At the end of pregnancy (week 36) it is up to the diaphragm. Accelerated growth of the uterus may indicate a multiple pregnancy. The fundus of the uterus usually drops a couple of weeks before delivery and becomes round in shape. At the same time the baby usually turns head down ready for delivery.

Many researchers [11,13] have mentioned various things that can affect the size of High Uterus Fundus (TFU), including: (a) Weight gain; (b) Mother's height; (c) Group / Ethnicity; (d) Parity; (e) Tobacco consumption habits.
Mothers with abnormal fetal weights may be affected by nutritional intake during pregnancy or illness that accompanies the mother, pregnant women with prepregnancy weight or excessive diet can cause the mother to have a large fetal weight beyond her pregnancy, and vice versa pregnant women with low pre-pregnancy weight and low nutritional intake can cause the mother to have a fetal weight interpretation less than her pregnancy [16].

Mothers with abnormal fetal weights may be affected by nutritional intake during pregnancy or illness that accompanies the mother, pregnant women with prepregnancy weight or excessive diet can cause the mother to have a large fetal weight beyond her pregnancy, and vice versa pregnant women with low pre-pregnancy weight and poor nutritional intake can cause the mother to have a fetal weight interpretation less than her pregnancy.

Another reason for concern is that some ingredients may be toxic when used alone or in combination with other compounds found in tobacco products. Examples include caffeine, ammonia, and taurine. In some cases, colouring agents added for aesthetic purposes may affect the overall toxicity of the resulting product. In addition, some ingredients have the ability to change the physical properties of tobacco smoke, including particle size of the emitting smoke. Particle size affects absorption levels of nicotine and other tobacco constituents in the lungs which can in turn increase blood nicotine levels. Furthermore, when ingredients are burned, new products of combustion are formed and these may be toxic or pharmacologically active. A key example is acetaldehyde, a known carcinogen produced from the burning of sugars added as sweeteners. Acetaldehyde works synergistically with nicotine to enhance the addictive potential of these products $[4,17]$

\section{CONCLUSIONS}

There is a relationship between chewing tobacco consumption during pregnancy with high fondues uteri (TFU) with $\mathrm{P}$ value $=0.028$. There is relationship of food consumption that is protein intake with TFU with value $\mathrm{p}=$ 0,018 . There is relationship of food consumption that is iron intake with TFU with value $\mathrm{p}=0,008$

\section{ACKNOWLEDGMENT}

The researchers would like to thank the leadership of University of Sumatera Utara for funding of research sourced from BPPTN funds in fiscal year 2017. Researchers also thanked respondents who are pregnant mother who are willing to be samples in this study.

\section{REFERENCES}

[1] Ministry of Health. 2013. Basic health research in 2013. Indonesian Agency for Health Research and Development

[2] World Health Organization. 2011. Global Adult Tobacco Survey: Indonesia Report. Regional Office for South-East Asia.

[3] Wang, Teresa W., Brandon Kenemer., Michael A. Tynan., Tushar Singh, And Brian King., 2016. Consumption Of Combustible And Smokeless Tobacco — United States, 2000-2015

[4] IAKMI. Tobacco Control Support Centre (TCSC). 2017

[5] Tirtosastro and Murdiyati. 2010. Tobacco and Cigarette Chemicals. Journal Of Agricultural Research And Development Vol 2 No 1 
[6] Budi Prasetyo , Hanifa Erlin Damayanti, Rizki Pranadyan, Pandu Hanindito Habibie, AC Romdhoni, Dian Islami. 2018. Maternal mortality audit based on district maternal health performance in East Java Province, Indonesia. Bali Medical Journal Vol 7 No 1: 61-67

[7] USAID. 2014. Report of the Mid-Term Evaluation - Expanding Maternal and Newborn Survival (EMAS) Program

[8] WHO. 2015. Strategies toward ending preventable maternal mortality (EPMM)

[9] Richard D Semba, Ashley A Campbell, Kai Sun, Saskia de Pee, Nasima Akhter, Regina Moench-Pfanner, Jee Hyun Rah, Jane Badham, Klaus Kraemer, Martin W Bloem. 2011. Paternal smoking is associated with greater food insecurity among poor families in rural Indonesia. Asia Pac J Clin Nutr 2011;20 (4):618-623

[10] Ma'rifah, Asirotul and Dita Ratna Fitri Ananda. 2014. The Relationship Between Weight Gain of Pregnant Mother With Fetal Weight Estimates in Mojokerto City. Thesis Health Science Institute

[11] Bahtera Bindavid Purba. 2013. Effect of Tobacco Tobacco Consumption on Low Birth Weight In Simalungun Regency. Thesis Master Program of Public Health Sciences Faculty of Public Health University of Sumatera Utara Medan
[12] WHO. 2014. Trends in maternal mortality: 1990 to 2013 : estimates by WHO, UNICEF, UNFPA. The World Bank and the United Nations Population Division: executive summary

[13] Richard D Semba, Leah M Kalm, Saskia de Pee, Michelle O Ricks, Mayang Sari and Martin W Bloem. 2016. Paternal smoking is associated with increased risk of child malnutrition among poor urban families in Indonesia.

[14] Sirajuddin., Abdullah Tamrin., Rudy Hartono., Manjilala. 2011. The Influence of Exposure to Cigarette Smoke against Birth Weight Infant In South Sulawesi. Food Nutrition Journal.

[15] Khoushabi, Fahimeh And G Saraswathi., 2010. Impact Of Nutritional Status On Birth Weight Of Neonates In Zahedan City, Iran. Nutrition Research And Practice. 4(4): 339-344

[16] Helsinki, 2012. A guidebook for expectant parents. National Institute For Health and Welfare. P (17). Erikoismedia Graphic Oy

[17] WHO. 2014. Iron Deficiency Anemia: Assessment, Prevention, and Control, A Guide For Programme Managers 